\title{
Ti-Ni 形状記憶合金細線の諸特性におよぼす樹脂粒子ピーニング処理の影響
}

\section{Effect of resin particle peening treatment on various properties of Ti-Ni shape memory alloy wire}

\author{
○正 南部紘一郎 ${ }^{* 1}$ ，奥宮正洋*1 \\ Koichiro NAMBU*1 and Masahiro OKUMIYA ${ }^{* 1}$ \\ *1 豊田工業大学 Toyota Technological Insutitue
}

Key Words : Ti-Ni shape memory alloy, Fatigue, Fine particle peening,

\section{1. 緒言}

近年, 超スマート技術や持続可能社会形成のために, 微細加工等による Micro Electro Mechanical Systems (MEMS) が必要とされている. MEMSの医療デバイスとして利用する場合, それらを構築する金属部材に繰返し応力や摩 擦など厳しい環境にさらされることが考えられるため，金属細線などの微小構造部材の疲労強度向上が必要不可 欠である. 一般的な構造部材の場合は熱処理等の表面改質処理によって, 疲労強度を向上させることが可能であ るが，熱処理等のひずみが発生することも知られている．微小構造部材ではこれらのひずみの発生が大きな問題 となることから, よりひずみの小さな表面改質処理を行う必要がある.

ひずみの小さな表面改質処理として, 被加工材よりも柔らかい粒子を使用した樹脂粒子ピーニング処理を提案 し, 従来のショットピーニング処理よりも高い疲労強度が得られることをこれまでの研究で明らかにしている. 本研究は医療用 MEMS デバイス構造部材の一つである Ti-Ni 形状記憶合金の諸特性に対して樹脂粒子ピーニング 処理がおよぼす影響について明らかにすることを目的とした。

\section{2. 試験片および表面改質処理条件}

供試材料として Ti-50wt\%Ni 形状記憶合金を使用した。試験片は直径 0.5mm, 長さ 100mm のワイヤー形 状とした．樹脂粒子ピーニング処理の投射材として，粒径 $500 \mu \mathrm{m}$ のクルミ（新モース硬さ：3）を使用し た. 比較材として粒径 $100 \mu \mathrm{m}$ のアルミナ粒子（新モース硬さ：12）を使用した. 投射圧力 $0.4 \mathrm{MPa}$, 処理 時間 $20 \mathrm{sec}$ で処理を実施した. 処理後に表面に残留した投射材を取り除くために超音波洗浄を行った.

\section{3. 実験方法}

ハイロックス社製デジタルマイクロスコープ（RH2000）にて 3 次元測定を実施した後，画像解析ソフト winroof2018 を用いて表面粗さ測定を実施した。島津製作所製ダイナミック超微小硬度計（DUH-211S）を 用いて表面から $200 \mu \mathrm{m}$ 深さまで，断面方向の硬さ分布を取得した．疲労試験には，自作の金属細線回転曲 げ疲労試験機を用いて実施し, 打切り回数は $10^{6}$ 回とした.

\section{4. 表面粗さ測定結果}

表面粗さを測定した結果, 受け入れママ材とクルミ材の Ra はほとんど変化がなく, アルミナ材では Ra は減少していた。一方で, デジタルマイクロスコープ画像では粒子の衝突痕が確認された.

\section{5 . 硬さ測定結果}

硬さ測定を行った結果，受け入れまま材のくぼみ読み取り硬さ平均が $370 H T 115$ であるのに対し，表面か ら $1 \mu \mathrm{m}$ 深さがクルミ材では 491HT115, アルミナ材では460HT115 といずれも上昇していた. また, 影響深 さはいずれも $10 \mu \mathrm{m}$ 程度であった。この結果から，投射材としてクルミを使用することで表面粗さをほと んど変化させずに硬さが上昇することを明らかにした.

\section{6. 結言}

Ti-Ni 形状記憶合金細線の表面改質処理法として樹脂粒子ピーニング処理を提案し，投射材としてクル ミを使用することで表面粗さを変化させずに硬さのみを向上できることを明らかにした. 